\section{Comparative Cold Tolerance in Diverse Turf Quality Genotypes of Perennial Ryegrass}

\author{
J.S. Ebdon ${ }^{1}$ and R.A. Gagne \\ Department of Plant and Soil Sciences, Stockbridge Hall, University of \\ Massachusetts, Amherst, MA 01003 \\ R.C. Manley \\ Department of Landscape Horticulture, Deering Hall, University of Maine, \\ Orono, ME 04469
}

Additional index words. freezing stress, electrolyte leakage, Lolium perenne, turfgrass

\begin{abstract}
Turf loss from freezing injury results in costly reestablishment, especially with turfgrasses such as perennial ryegrass (Lolium perenne L.) having poor low-temperature tolerance. However, no studies have been conducted to investigate the relative importance of low-temperature tolerance and its contribution to turfgrass quality (performance) in northern climates. The objective of this research was to compare critical freezing thresholds $\left(\mathrm{LT}_{50}\right)$ of 10 perennial ryegrass cultivars representing contrasting turf-quality types (five high- and five low-performance cultivars). Cultivar selection was based on turfgrass quality ranking (top and bottom five) from the 1997 National Turfgrass Evaluation Program (NTEP) trial conducted at the Maine (Orono) location. Ten freeze-stress temperatures $\left(-3\right.$ to $\left.-21^{\circ} \mathrm{C}\right)$ and a nonfrozen control $\left(5^{\circ} \mathrm{C}\right)$ were applied to 5 -month-old plants. Acclimated (AC) plant material maintained in an unheated polyhouse during the fall and winter in Massachusetts was compared to nonacclimated (NA) plant material (grown at $18{ }^{\circ} \mathrm{C}$ minimum in a greenhouse). Low-temperature tolerance was assessed using whole-plant survival and electrolyte leakage (EL). Estimates of $\mathrm{LT}_{50}$ were derived from fitted EL and survival curves using nonlinear regression. High-performance cultivars were able to tolerate significantly lower freeze-stress temperatures indicated by less EL and greater survival compared to low-performance cultivars. The EL method had good predictive capability for low-temperature survival. Acclimated tissues and highperformance cultivars had significantly flatter EL curves and lower mortality rates. These results underscore the importance of selecting cold-tolerant perennial ryegrass genotypes for adaptation to northern climates.
\end{abstract}

Turf loss due to freezing injury results in costly reestablishment, increased weed pressure and associated herbicide cost, increased soil loss from erosion, and a reduction in the aesthetic value and function of turf areas (DiPaola and Beard, 1992). Turfgrass species and cultivars vary widely in their tolerance to freezing stress. Perennial ryegrass is considered to be the most susceptible cool-season grass to low-temperature kill (Beard, 1973; Gusta et al., 1980). In a study of cold tolerance among nine cool-season turfgrasses, Gusta et al. (1980) reported $\mathrm{LT}_{50}$ s ranging from $-35^{\circ} \mathrm{C}$ for creeping bentgrass (Agrostis palustris Huds.) to -5 to $-15^{\circ} \mathrm{C}$ for cultivars of perennial ryegrass. Despite the poor low-temperature tolerance of perennial ryegrass, its popularity and use continues to increase with release of several new and improved cultivars (Meyer and Funk, 1989; Watson et al., 1992; Young and Baker, 1995).

Received for publication 1 June 2001. Accepted for publication 10 Jan. 2002. This research was supported in part by grants from the Massachusetts Turf and Lawn Grass Association and the Healy Endowment Grant.

${ }^{1}$ To whom reprint requests should be addressed. E-mail: sebdon@pssci.umass.edu.
The temperature at which plant mortality occurs is a complex interaction among environmental, cultural, and genetic factors affecting hardening (Beard, 1973; Blum, 1988; Humphreys, 1989). In perennial ryegrass, whole-plant survival to freeze-stress temperatures depends on tiller production for regrowth, and therefore superior tillering may enhance recovery from low-temperature stress (Eagles et al., 1993). The apex of the main tiller of perennial ryegrass is killed at higher temperatures than other regions of the crown due to differential hardening within this tissue. Differential hardening within crown tissue has also been reported for other grasses (Beard and Olien, 1963; Shibata and Shimada, 1986; Tanino and McKersie, 1985). High shoot density (rate of tillering) is a major component contributing to improved turfgrass quality (NE57 Technical Research Committee, 1977) and along with genetic variation in the level of hardening could provide a mechanism for improved freeze-stress recovery. Turfgrass quality is an index of color, density, leaf texture, disease resistance, mowing qualities, and stress tolerance (Turgeon, 1999), including several stresses operating during winter(Beard, 1973). Therefore, freezing stress is only one of several turf-forming traits affecting turfgrass survival and quality.
Recovery (survival) evaluations after lowtemperature exposure is a reliable method for assessing low-temperature tolerance (Steponkus, 1978). This procedure is timeconsuming and does not provide direct information regarding the mechanisms that cause death of the freeze-stressed plant. To assess the level of cell injury due to low-temperature stress, the EL technique is commonly used as an alternative to regrowth-survival because EL is more rapid and has been shown to be correlated with survival (Cardona et al., 1997; Fry et al., 1991; Gusta et al., 1980; Maier et al., 1994). Furthermore, slope estimates derived from EL curves when plotted against temperature are good indicators of mortality rate during freezing stress (Zhu and Liu, 1987). Studies have shown, however, that EL may underestimate actual survival (Cardona et al., 1997; Fry et al., 1993) because a high leakage level may not always equate to greater membrane injury when plants are allowed to adjust to low temperature through acclimation (Uemura et al., 1995; Uemura and Steponkus, 1994). Therefore, survival evaluations should be included with EL assays to provide a more reliable assessment of actual low-temperature survival.

Poor cold hardiness is a major factor limiting perennial ryegrass growth in the northern United States. While lack of low-temperature hardiness in perennial ryegrass has been recognized, we are unaware of any studies to determine the extent of freezing tolerance and its relative correlation to turfgrass performance in northern climates. The objective of this research was to compare critical freezing thresholds of perennial ryegrass cultivars representing contrasting turfgrass quality types, evaluated using whole-plant survival and EL methods under AC and NA conditions.

\section{Materials and Methods}

Cultivar selections. The criteria for cultivar selection was based on turf quality ranking. Specifically, the top five and bottom five cultivars (high- and low-performance cultivars, respectively) were selected from the 1997 Orono, Maine, NTEP report (USDA, 1997). The NTEP perennial ryegrass trial was initiated in Sept. 1994 and included 96 entries. No maintenance information (fertilization, mowing, and irrigation) or environmental data (soil and climatic) was available from the NTEP reports on the Maine location. However, the Maine location is the most northern NTEP location in New England, with an average January temperature of $-10.3^{\circ} \mathrm{C}$ for the period from 1994 through 1997 (NRCC report, 1998). High-performance cultivars included 'LRF94-C8', 'Palmer III', 'Prelude III', 'Repell III', and 'Top Hat', and low-performance cultivars included 'DSV-NA-9401', 'DSV-NA9402', 'Linn', 'Pennfine', and 'SR-4010'.

Pure seed from each cultivar was obtained directly from the breeder. Plants were established from seed under mist in the greenhouse beginning 23 Sept. 1998 through 2 Oct. 1998. Seed was sown (seeding rate, $439 \mathrm{~kg} \cdot \mathrm{ha}^{-1}$ ) in 5 cm-diameter $\times 17.8$-cm-deep $(0.089 \mathrm{~L})$ pots 
(Hummert International, Earth City, Mo.) filled with a commercial planting mix consisting of peat, perlite, and vermiculite (Sierra Customblend Bale Mix; The Scotts Co., Marysville, Ohio). A control-release fertilizer (Osmocote 14N-6.2P-11K, The Scotts Co.) was incorporated into the potting mix at planting at $146 \mathrm{~kg} \cdot \mathrm{ha}^{-1}$ of $\mathrm{N}$. Initial soil $\mathrm{pH}$ of the potting mix was 5.9. No nutrient deficiencies (macro and minor elements) were identified based on soil test results.

Preconditioning environments. After plants reached the $4^{\text {th }}$ leaf stage (between 13 and 19 Oct. 1998), half of the containers of each cultivar were moved to a cool greenhouse (14 to $17{ }^{\circ} \mathrm{C}$ average daily temperature) before being placed in the field for acclimation. The second half of the containers were moved to a warm greenhouse (18 to $22{ }^{\circ} \mathrm{C}$ average daily temperatures) representing NA conditions. Genotypes were evaluated under two treatment environments representing AC (hardened) and NA (nonhardened). All plants were watered as needed and mowed weekly to $\approx 5$ $\mathrm{cm}$ above soil level. The greenhouse temperatures were monitored hourly using an air-gas thermocouple attached to a printing thermometer (model 422314; Extech Instruments, Cole Palmer, Vernon Hills, Ill.).

On 9 Dec. 1998, container plants from the cool greenhouse were transferred to the field and placed in a cold frame in a covered, but open-ended, polyhouse at the Univ. of Massachusetts Turfgrass Research Farm in South Deerfield, Mass. Containers were placed randomly on the soil surface. Home-building thermal insulation (Corning R13, $8.75 \mathrm{~cm}$ thickness, Corning, N.Y.) was wrapped around the periphery of the containers in order to maintain the root-zone temperatures as close to natural in-ground temperature (see Fig. 1). Plants were maintained in the polyhouse for the remainder of the fall and winter to simulate field-acclimation as closely as possible. Air, crown, and root-zone temperatures were monitored using copper-constantan thermocouples connected to a datalogger (21X; Campbell Scientific, Logan, Utah). Thermocouples were also placed outside the polyhouse on the soil surface and $2.5 \mathrm{~cm}$ into the soil.

Freeze-shock recovery (survival) evaluations. Freeze shock and subsequent recovery of plant material was evaluated by first submitting samples to 11 treatment temperatures consisting of a nonfrozen control $\left(5^{\circ} \mathrm{C}\right)$, and 10 freeze-stress temperatures: $-3,-5,-7,-9$, $-11,-13,-15,-17,-19$, and $-21{ }^{\circ} \mathrm{C}$. Treatment temperatures were applied using a ScienTemp programmable freezer (ScienTemp Corp., Adrian, Mich.).

A set of 20 randomly selected container plants representing 20 treatment combinations (10 cultivars $\times$ two environments) were used at each treatment temperature. Accordingly, to expose all cultivar-environment combinations to the full range of 11 treatment temperatures a total of 220 containers were used per replicate. Acclimated plant samples were taken during early February through mid-March from plant material maintained in the polyhouse.
Plant material was washed free of soil using cold water and separated into individual plants. From each plant container (cultivar-environment combination), 10 individual plant samples were selected. Shoots and roots were each trimmed to $2 \mathrm{~cm}$. To ensure ice nucleation, the 10 plant samples were wrapped in paper toweling moistened with deionized water and placed into poly-freezer bags for freeze-stress treatment. During sample preparation, all plant material was temporarily stored at $5{ }^{\circ} \mathrm{C}$.

After preparation, all the freezer bags containing samples were placed in the freezer at the same time and left overnight at $-2{ }^{\circ} \mathrm{C}$. Nonfrozen control samples remained overnight at $5{ }^{\circ} \mathrm{C}$. Treatment temperatures were adjusted manually and monitored using six copper-constantan thermocouples attached to a datalogger (CR10X, Campbell Scientific). Treatment temperatures -3 to $-11{ }^{\circ} \mathrm{C}$ were applied the first day. The freezer was then left at $-11{ }^{\circ} \mathrm{C}$ overnight and the remainder of the freezing schedule to $-21^{\circ} \mathrm{C}$ was completed the following day. The temperature of the plant material was cooled to the desired treatment level at a rate of $2{ }^{\circ} \mathrm{C} / \mathrm{h}$ maximum. The material was then allowed to remain at that temperature for a minimum of $1 \mathrm{~h}$. After each treatment-temperature exposure, 20 freezer bags corresponding to the 20 cultivar-environment combinations were removed from the freezer and allowed to thaw for a minimum of $12 \mathrm{~h}$ at $5{ }^{\circ} \mathrm{C}$.

Samples were replanted in cell trays and placed in the warm greenhouse $\left(\approx 20^{\circ} \mathrm{C}\right.$ average air temperature) for a 4 -week recovery period. Plants with any green surviving tissues or any new growth from even one shoot were counted as survivors, whereas others were counted as dead. Percent survival was calculated as: survival $(\%)=($ no. of plants survived $\div$ total no. of plants $) \times 100$. This procedure was repeated for a total of four replications requiring 880 container plants for evaluating wholeplant survival.

Electrolyte leakage evaluations. Plant material was prepared as described for survival evaluations. From each plant container, 15 individual plant samples were prepared for temperature exposure. Leaves and roots were removed, leaving only crowns. A total of five crown samples were placed into each of three test tubes and stoppered. To ensure ice nucleation, test tubes were filled with $4 \mathrm{~mL}$ deionized water, frozen, and held at $-2{ }^{\circ} \mathrm{C}$ before plant material was added. Crowns were then placed in the test tubes in contact with the ice and an additional $1 \mathrm{~mL}$ deionized water was added. During sample preparation plant material was temporarily stored at $5{ }^{\circ} \mathrm{C}$.

After sample preparation, the treatmenttemperature schedule and protocol used for freeze-shock survival were followed. After each treatment-temperature exposure, three test tubes per cultivar-environment combination were removed from the freezer and allowed to thaw for a minimum of $12 \mathrm{~h}$ at $5{ }^{\circ} \mathrm{C}$. Samples were then subjected to infiltration (test tubes uncovered) under partial vacuum (0.033 MPa) for $20 \mathrm{~min}$, then incubation (test tubes covered) at $5^{\circ} \mathrm{C}$ for $12 \mathrm{~h}$, and then placed on a centrifugal (rotary) shaker table $(\approx 150$ rpm) at $\approx 21^{\circ} \mathrm{C}$ for $8 \mathrm{~h}$. Initial conductivity (IC) of the extract of each test tube was measured using a conductivity bridge (model 1054; VWR Scientific, Boston). Crowns were then killed by overnight exposure to $-40{ }^{\circ} \mathrm{C}$. Samples were thawed at room temperature for at least 4 $\mathrm{h}$ and placed on a shaker table for $2 \mathrm{~h}$ at room temperature, after which the final conductivity (FC) of the extract was measured. Electrolyte leakage was expressed as a relative percentage: $\mathrm{EL}(\%)=(\mathrm{IC} \div \mathrm{FC}) \times 100$. The three test tube samples were averaged, and the procedure was repeated for a total of three replications requiring 660 container plants for the EL study.

Statistical analysis and $L T_{50}$ estimates. Due to the large number of samples and the limited physical size of the freezer and support equipment, it was necessary to partition the testing workload. The total time from start to finish for assessing all replications for survival and EL was 7 weeks. Although time delay between assessment methods could have introduced potential differences in acclimation and deacclimation of AC plant material maintained outside in the polyhouse (White and Smithberg, 1980), this effect was minimized by alternating replications (blocks) for individual assessments between survival and EL evaluations. Consequently, time was used as a blocking variable.

Lethal temperatures at which $50 \%$ survival and EL occurred $\left(\mathrm{LT}_{50}\right)$ was determined mathematically by curve fitting using a four-parameter sigmoid model (Sigma Plot, SPSS, Chicago). Parameter estimates were substituted back into the nonlinear equation and the temperature where Y (survival or EL) is $50 \%$ was determined for each replicate and treatment combination (cultivar $\times$ preconditioning environment). A four parameter nonlinear regression model as described by Cardona et al. (1997) was used to estimate the slope of the EL curve by fitting EL to temperature. Slope estimates were determined using the user defined subroutine of nonlinear regression (Sigma Plot).

Analysis of variance (ANOVA) of $\mathrm{LT}_{50}$ estimates (EL and survival) and slope estimates were analyzed by MINITAB (State College, $\mathrm{Pa}$.). Using a complete factorial arrangement in a randomized complete-block design, 10 cultivars and two environments were analyzed as fixed-effect treatment factors. Cultivar sum of squares (SS) were partitioned into a set of orthogonal single degree of freedom (df) contrast to test for differences between the combined means comparing highand low-turfgrass performance cultivars. Additionally, contrasts among high- and lowcultivar types were compared to test for differences within each turfgrass performance group. Cultivar comparisons were crossed with preconditioning environment to partition cultivar $\times$ environment interaction SS. No departures from the assumptions of the ANOVA model were detected in homogeneity of variance or departures from normality. 


\section{Results and Discussion}

Survival and EL, when plotted against temperature, followed a sigmoidal response, typical for this type of experiment (Cardona et al., 1997; Zhu and Liu, 1987). Cultivar (high- vs. low-performance types) and preconditioning environment (AC and NA) were significant factors affecting low-temperature hardiness, based on survival and EL evaluations (Table 1). Cold tolerance among cultivars used in this study was dependent on whether or not plants had been allowed to acclimate to low temperatures as indicated by significant interactions between cultivar (C) and environment (E) following partitioning of the $\mathrm{C} \times$ E interaction $\mathrm{SS}$ (Table 1). Figure 1 shows the polyhouse (acclimating environment) mean daily soil vs. plant media temperature at the surface and 2.5 $\mathrm{cm}$ depth. Figure 2 shows the mean daily air temperature for both AC (polyhouse) and NA (greenhouse) environments for the duration of the experimental period. Generally, soil and plant media temperatures at the $2.5-\mathrm{cm}$ depth were less variable than surface temperatures, and soil temperatures were less variable than plant media temperatures (Fig. 1). Surface temperatures recorded and averaged over a 24-h period for plant media during acclimation reached a low of $-12.6^{\circ} \mathrm{C}$ on $15 \mathrm{Jan}$. (Fig. 1) and may have approached or exceeded the critical thresholds reported for some perennial ryegrass cultivars (Gusta et al., 1980).

Effect of preconditioning environment on freezing tolerance. Acclimated (hardened) plants exhibited greater freeze-stress tolerance than NA plants indicated by lower (more negative) $\mathrm{LT}_{50}$ estimates associated with $\mathrm{AC}$ tissues (Table 2). Acclimated tissues had a mean survival $\mathrm{LT}_{50}$ of $-8.6^{\circ} \mathrm{C}$ compared to -1.6 ${ }^{\circ} \mathrm{C}$ for NA plants. The range in cultivar $\mathrm{LT}_{50}$ was similar for $\mathrm{AC}\left(-2.8\right.$ to $\left.-12.6^{\circ} \mathrm{C}\right)$ and NA $\left(4.2\right.$ to $-4.9^{\circ} \mathrm{C}$ ) plants (Table 2). Gusta et al. (1980) reported a similar range $\left(-5\right.$ to $\left.-15^{\circ} \mathrm{C}\right)$, but lower $\mathrm{LT}_{50} \mathrm{~s}$ for field-hardened perennial ryegrass cultivars in Colorado. The differences between the findings of Gusta et al. (1980) and ours is in part due to the many factors affecting the level of hardening, such as freezing rate, moisture content of tissues, and the type of tissue (Anderson et al., 1988; Beard, 1973), as well as experimental procedures, including the cooling rate, method of ice nucleation, and duration of freezing and thawing (Alberdi and Corcuera, 1991).

Acclimated plants also tolerated significantly lower freezing temperatures compared to NA tissue based on EL evaluations (Table 2). Acclimated plants had a mean EL $\mathrm{LT}_{50}$ of $-5.1^{\circ} \mathrm{C}$ compared to $-1.7{ }^{\circ} \mathrm{C}$ for NA tissue. Since $\mathrm{LT}_{50}$ for survival following acclimation was lower by $\approx 3.5{ }^{\circ} \mathrm{C}$ compared to those derived from fitted EL curves, EL underestimated actual survival. In paspalum (Paspalum vaginatum Swartz) (Cardona et al., 1997) and centipedegrass [Eremochloa ophivroides (Munro) Hack] (Fry et al., 1993), EL assays underestimated survival by $\approx 2.0$ to $3.5^{\circ} \mathrm{C}$.

Agreement between survival and EL results in cultivar ranking based on $\mathrm{LT}_{50}$ estimates was noted. Estimates of $\mathrm{LT}_{50} \mathrm{~s}$ derived
Table 1. Mean squares from analysis of variance of slope estimates derived from electrolyte leakage (EL) curves and $\mathrm{LT}_{50}$ estimates derived from regrowth-survival and EL curves.

\begin{tabular}{lcccc}
\hline \hline & & \multicolumn{3}{c}{ Mean squares } \\
\cline { 3 - 5 } Source of variation & df & Survival LT $_{50}$ & EL LT $_{50}$ & EL slope $^{z}$ \\
\hline Total & $79(59)^{y}$ & & & \\
Block & $3(2)^{y}$ & 27.59 & 4.62 & $11.56^{* *}$ \\
Cultivar (C) & 9 & $50.60^{* * * *}$ & $11.68^{* * *}$ & 1.04 \\
High vs. low (HL) & 1 & $259.85^{* * *}$ & $66.97^{* * *}$ & 1.47 \\
Among high (H) & 4 & 5.75 & 2.40 & 0.08 \\
Among low (L) & 4 & $43.14^{*}$ & 7.14 & 1.14 \\
Environment (E) & 1 & $989.54^{* * *}$ & $296.82^{* * * *}$ & $60.40^{* * *}$ \\
$\mathrm{C} \times \mathrm{E}$ & 9 & 21.38 & 4.35 & 2.97 \\
HL $\times$ E & 1 & 0.70 & $9.56^{*}$ & $4.06^{*}$ \\
$\mathrm{H} \times \mathrm{E}$ & 4 & 6.83 & 2.36 & 0.35 \\
$\mathrm{~L} \times \mathrm{E}$ & 4 & $41.10^{*}$ & 5.04 & $5.31^{*}$ \\
Error & $57(38)^{y}$ & 11.66 & 3.20 & 1.76 \\
\hline
\end{tabular}

${ }^{\mathrm{x}}$ Mean squares multiplied by 100 for ease of presentation.

${ }^{y}$ Numbers in parentheses represent df corresponding to EL $\mathrm{LT}_{50}$ and EL slope.

$*, * * * * *$ Significant at $P \leq 0.05,0.01$, and 0.001 levels, respectively.

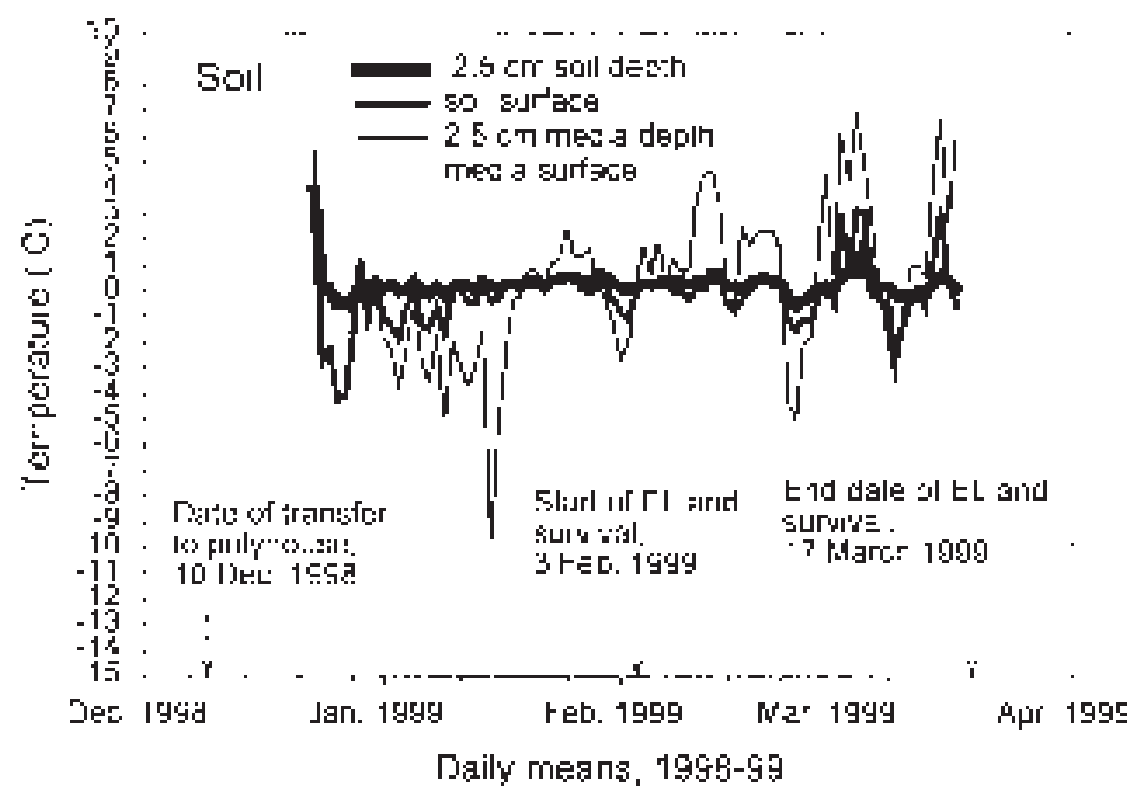

Fig. 1. Mean daily soil temperature comparison between soil and plant container media at various depths in the polyhouse (acclimating environment) during the experimental period.

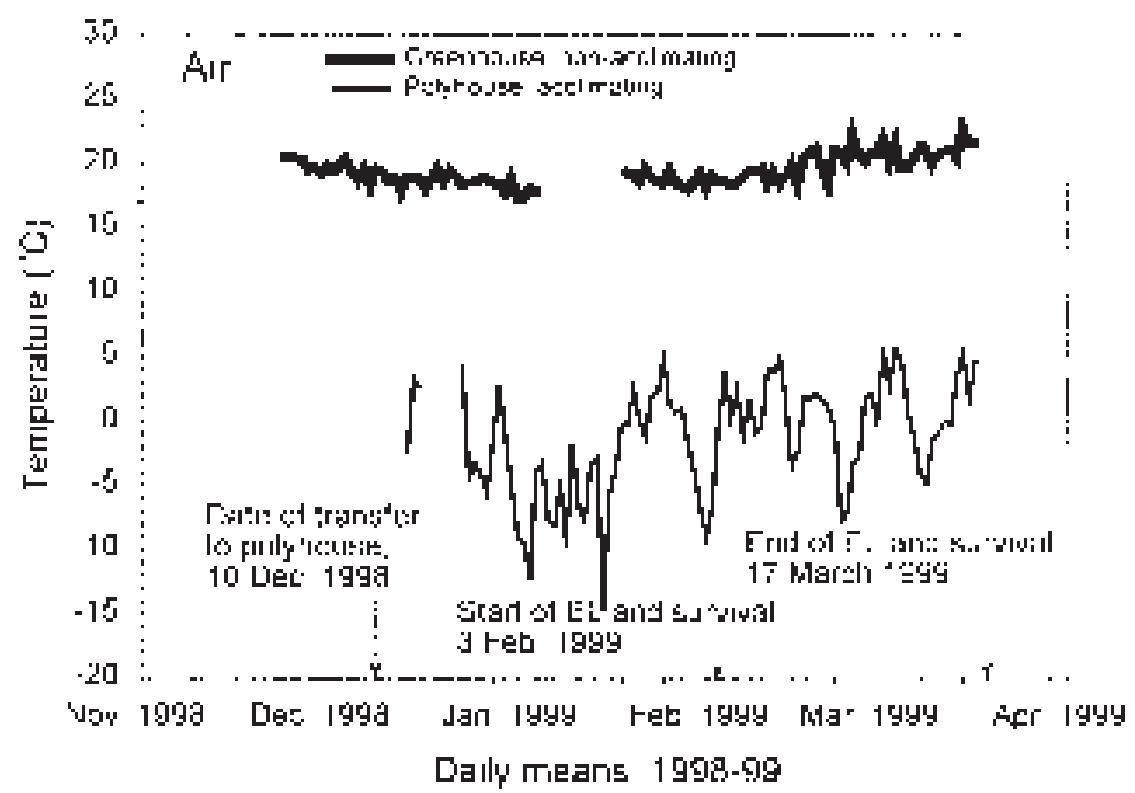

Fig. 2. Mean daily air temperature comparison between acclimating (polyhouse) and nonacclimating (greenhouse) environments. 
Table 2. Means for $\mathrm{LT}_{50}$ values and slope estimates for high- and low-performance perennial ryegrass cultivars exposed to freeze-stress temperatures following preconditioning to acclimated (AC) and nonacclimated (NA) environments.

\begin{tabular}{|c|c|c|c|c|c|c|c|c|c|}
\hline \multirow[b]{3}{*}{ Cultivar } & \multicolumn{3}{|c|}{ Survival $\mathrm{LT}_{50}\left({ }^{\circ} \mathrm{C}\right)$} & \multicolumn{3}{|c|}{$\mathrm{EL} \mathrm{LT}_{50}\left({ }^{\circ} \mathrm{C}\right)$} & \multicolumn{3}{|c|}{ EL slope } \\
\hline & \multicolumn{2}{|c|}{ Environment $^{\mathrm{z}}$} & \multirow[b]{2}{*}{ Cultivar $^{\mathrm{w}}$} & \multicolumn{2}{|c|}{ Environment $^{y}$} & \multirow[b]{2}{*}{ Cultivarv $^{v}$} & \multicolumn{2}{|c|}{ Environment $^{\mathrm{x}}$} & \multirow[b]{2}{*}{ Cultivar } \\
\hline & $\mathrm{AC}$ & NA & & $\mathrm{AC}$ & NA & & $\mathrm{AC}$ & NA & \\
\hline \multicolumn{10}{|l|}{ High performance } \\
\hline LRF-94-C8 & -12.1 & -4.0 & -8.0 & -7.0 & -1.3 & -4.2 & 0.40 & 0.65 & 0.53 \\
\hline Palmer III & -10.2 & -1.6 & -5.9 & -6.4 & -2.4 & -4.4 & 0.41 & 0.68 & 0.54 \\
\hline Prelude III & -9.0 & -4.4 & -6.7 & -5.0 & -2.3 & -3.6 & 0.42 & 0.59 & 0.51 \\
\hline Repell III & -10.3 & -2.4 & -6.4 & -6.1 & -3.0 & -4.6 & 0.40 & 0.68 & 0.54 \\
\hline Top Hat & -10.0 & -4.9 & -7.4 & -4.4 & -1.6 & -3.0 & 0.30 & 0.60 & 0.45 \\
\hline High mean & -10.3 & -3.5 & -6.9 & -5.8 & -2.1 & -3.9 & 0.39 & 0.64 & 0.51 \\
\hline \multicolumn{10}{|l|}{ Low performance } \\
\hline DSV-9401 & -2.8 & -2.0 & -2.4 & -5.0 & -0.2 & -2.6 & 0.57 & 0.58 & 0.58 \\
\hline DSV-9402 & -8.2 & -2.0 & -5.1 & -5.9 & 0.3 & -2.8 & 0.39 & 0.56 & 0.47 \\
\hline Linn & -6.7 & 0.6 & -3.1 & -2.9 & 0.5 & -1.2 & 0.38 & 0.78 & 0.58 \\
\hline Pennfine & -12.6 & 0.9 & -5.8 & -6.3 & 1.6 & -2.3 & 0.42 & 0.66 & 0.54 \\
\hline SR-4010 & -4.2 & 4.2 & 0.0 & -2.2 & 1.7 & -0.2 & 0.59 & 0.52 & 0.56 \\
\hline Low mean & -6.9 & 0.3 & -3.3 & -4.5 & 0.8 & -1.8 & 0.47 & 0.62 & 0.55 \\
\hline Environment mean & -8.6 & -1.6 & --- & -5.1 & -1.7 & --- & 0.43 & 0.63 & --- \\
\hline
\end{tabular}

${ }^{\mathrm{z}} \mathrm{LSD}_{0.05}$ is -4.8 , for comparing among cultivar-environment combinations (row and column) for survival $\mathrm{LT}_{50}$.

${ }^{\mathrm{y}} \mathrm{LSD}_{0.05}$ is -2.9 , for comparing among cultivar-environment combinations (row and column) for EL $\mathrm{LT}_{50}$. ${ }^{\mathrm{x}} \mathrm{LSD}_{0.05}$ is 0.22 , for comparing among cultivar-environment combinations (row and column) for EL slope. ${ }^{\mathrm{w}} \mathrm{LSD}_{0.05}$ is -3.4 , for comparing among cultivar means (column) for survival $\mathrm{LT}_{50}$.

${ }^{\mathrm{v}} \mathrm{LSD}_{0.05}$ is -2.1 , for comparing among cultivar means (column) for EL $\mathrm{LT}_{50}$.

from EL curves were correlated with survival evaluations for hardened $(r=0.69, P \leq 0.05)$ and nonhardened $(r=0.76, P \leq 0.01)$ ryegrass plants. This is consistent with other studies that have suggested EL as a potential screening method for improved low-temperature tolerance (Cardona et al., 1997; Fry et al., 1991; Gusta et al., 1980; Maier et al., 1994; Murdoch et al., 1990).

Turfgrass performance and associated freezing tolerance. High-performance cultivars were able to tolerate significantly lower freeze-stress temperatures than low-performance cultivars. This is indicated by lower $\mathrm{LT}_{50}$ estimates with high-performance cultivars vs. the low-cultivar group based on survival $\left(-6.9^{\circ} \mathrm{C}\right.$ vs. $\left.-3.3{ }^{\circ} \mathrm{C}\right)$ and $\mathrm{EL}\left(-3.9^{\circ} \mathrm{C}\right.$ vs . $\left.-1.8^{\circ} \mathrm{C}\right)$ (Table 2$)$. The significant $(P \leq 0.001)$ single df contrast comparing high and low cultivars in survival and EL (Table 1) underscores the superior low-temperature tolerance of high-performance cultivars. Similarly, differences in survival between performance groups were also detected in $\mathrm{AC}$ and NA plants, suggesting that superior cold tolerance with high-performance cultivars could be identified even when cultivars had not adjusted to low temperature through acclimation. However, the significant interaction $(P \leq 0.05)$ in $\mathrm{EL} \mathrm{LT}_{50}$ between cultivar performance group and preconditioning environment $(\mathrm{HL} \times \mathrm{E}$ interaction, Table 1) reveals that differences were only detected between high- and lowperformance cultivars in NA plants.

'Pennfine' AC plants had a mean $\mathrm{LT}_{50}$ for survival that was similar in low-temperature tolerance to cultivars from the high-performance group. For example, high-performance cultivars ranged from -9.0 ('Prelude III') to $-12.1{ }^{\circ} \mathrm{C}$ ('LRF-94-C8') while $\mathrm{LT}_{50}$ s for the low-cultivar group ranged from -2.8 ('SR4010 ') to $-12.6^{\circ} \mathrm{C}$ ('Pennfine'). This departure in freeze-stress tolerance associated with 'Pennfine' contributed to the significant dif- ference $(P \leq 0.05)$ observed among low-performance cultivars in survival $\mathrm{LT}_{50}$ (Table 1). However, the superior cold tolerance with 'Pennfine' was only detected following acclimation and therefore was dependent on the preconditioning environment (as indicated by the significant $\mathrm{L} \times \mathrm{E}$ interaction, Table 1).

'Pennfine' shares freeze-stress characteristics in common with high-performance genotypes. Obviously, improved low-temperature hardiness alone does not necessarily equate to superior turfgrass quality. However, these results indicate that superior cold tolerance appears to be a characteristic universal to perennial ryegrass genotypes that perform best in northern climates.

Slope estimates, turfgrass performance, and freezing tolerance. The slope of the EL curve is an important indicator of mortality resulting from freeze stress (Gudleifsson et al., 1986; Zhu and Liu, 1987). Differences in slope between hardened and nonhardened perennial turfgrasses (Rajashekar et al., 1983) and forage grasses (Gudleifsson et al., 1986) suggest that most hardy species have smaller slopes (flatter curves), while nonhardy species are associated with EL curves having steep slopes. Slope estimates derived from EL curves indicated no difference was detected among individual cultivars (Table 1). However, differences were identified between preconditioning environment and turf performance groups. Furthermore, a highly significant block effect $(P \leq 0.01$, Table 1$)$ was detected, suggesting that blocking over time was effective in controlling variation in mortality (slope) during the 7-week freeze-stress evaluation period. Slope of the EL curve increased significantly with time. Specifically, the plant material from the first replication (block) had flatter slopes (0.48) compared to the last replicate (block three, EL slope of 0.62) indicating that plants were de-acclimating by the beginning of the last replication in early to
mid-March (Fig. 1). Previous studies conducted in Minnesota have shown that coolseason turfgrass de-acclimated rapidly during the March and April period (White and Smithberg, 1980). So blocking was an effective experimental design in controlling (partitioning) experimental error.

Acclimated plants had significantly $(P \leq$ 0.001 , Table 1) smaller slopes (0.43) compared to NA plants (0.63) (Table 2). The flatter slope associated with hardened crowns suggest that AC plants had reduced leakage levels and less membrane damage compared to NA tissues. A difference in slope also implies that acclimation affected the rate of membrane leakage in these cultivars. Similar results between hardened and nonhardened turfgrass have also been reported (Cardona et al., 1997; Rajashekar et al., 1983). However, not all cultivars of perennial ryegrass in this study acclimated to low temperature by reducing membrane leakage rates indicated by significantly smaller slope estimates. Low-performance cultivars, including 'DSV-9401', 'DSV9402', and 'SR-4010', had similar slope estimates before and following acclimation based on $\mathrm{LSD}_{0.05}$ values (Table 2). In contrast, 'Prelude III' was the only high-performance cultivar that did not have a significantly smaller slope after adjusting to acclimation. The slope of the EL curve is generally correlated (positively) with the lethal killing temperature of the tissue (Zhu and Liu, 1987). In our studies, the slope of the EL curve for AC tissues were also correlated with cultivar $\mathrm{LT}_{50}$ for survival $(r=0.73, P \leq 0.05)$.

Differences in slope between performance groups were only detected for AC tissues. The high-performance cultivars had significantly $(P \leq 0.05)$ smaller slopes $(0.39)$ following acclimation compared to the low performance group (mean slope of 0.47 , Table 2). This suggests that differences in the level of hardening at the cell level between high and lowperformance cultivars occurred only following acclimation. Differences in slope among individual cultivars were only detected in low performance cultivars for NA tissues based on $\mathrm{LSD}_{0.05}$ values (Table 2). For example, 'SR4010 ' had a significantly smaller slope (0.52) than Linn perennial ryegrass (slope estimate of 0.78). Therefore, differences in slope between contrasting turf quality types and among low performance cultivars were dependent on the preconditioning environment as indicated by the significant $\mathrm{HL} \times \mathrm{E}$ and $\mathrm{L} \times \mathrm{E}$ interaction (Table 1).

According to Eagles et al. (1993), improved survival of hardened perennial ryegrass to freezing temperature is dependent on the ability for regrowth from lateral tiller buds and not attributed to improved hardiness of the main apex. The release of lateral tiller buds from apical dominance after death of the main apex is the method of recovery in perennial ryegrass. They reasoned that profuse tillering could have a beneficial effect on recovery by providing more tiller buds as potential sites for regrowth. Fall shoot density ratings obtained from NTEP reports indicated that high-performance cultivars had significantly $(P \leq 0.05)$ 
more shoots compared to the low-performance group (USDA, 1997). The potential for greater tillering capacity with high-performance cultivars could provide a mechanism for superior winter survival as suggested by Eagles et al. (1993) along with intraspecific differences in the level of hardening that was observed between turf performance groups.

This study showed that perennial ryegrass cultivars selected for superior turfgrass quality in northern climates generally had improved low-temperature tolerance indicated by higher freeze-stress survival, lower leakage levels, and lower mortality rates (flatter EL curves) compared to their poor performing counterparts. Although some poor performing cultivars such as 'Pennfine' may also have improved cold tolerance, these results suggest that freeze-stress resistance appears to be an important selection criteria for developing perennial ryegrass cultivars for northern climates such as Maine. To that end, screening for low-temperature survival using electrolyte leakage methods may be useful for identifying superior genotypes.

\section{Literature Cited}

Alberdi, M., and L.J. Corcuera. 1991. Cold acclimation in plants. Phytochemistry 30:3177-3184.

Anderson, J.A., M.P. Kenna, and C.M. Taliaferro. 1988. Cold hardiness of Midiron and Tifgreen bermudagrass. HortSience. 23:748-750.

Beard, J.B. 1973. Turfgrass: Science and culture. Prentice-Hall, N.J.

Beard, J.B. and C.R. Olien. 1963. Low temperature injury in the lower portion of Pоа аппиа L. crowns. Crop Sci. 3:362-363.

Blum, A. 1988. Plant breeding for stress environments. CRC Press, Boca Raton, Fla. p. 114-132.

Cardona, C.A., R.R. Duncan, and O. Lindstrom. 1997. Low temperature tolerance assessment in paspalum. Crop Sci. 37:1283-1291.

DiPaola, J.M., and J.B. Beard. 1992. Physiological effects of temperature stress, p. 231-267. In:
D.V. Waddington, R.N. Carrow, and R.C. Shearman (eds.). Turfgrass-Agronomy Monograph no. 32. ASA, CSSA, and SSSA, Madison, Wis

Eagles, C.F., J. Williams, and D.V. Louis. 1993. Recovery after freezing in Avena sativa L., Lolium perenne L., and L. multiflorum Lam. New Phytol. 123:477-483.

Fry, J.D., N.S. Lang, and R.G.P. Clifton. 1991. Freezing resistance and carbohydrate composition of 'Floratam' St. Augustinegrass. TurfScience 26:1537-1539.

Fry, J.D., N.S. Lang, R.G.P. Clifton, and F.P. Maier. 1993. Freezing tolerance and carbohydrate content of low temperature acclimated and nonacclimated centipedegrass. Crop Sci. 33:1051-1055.

Gudleifsson, B.E., C.J. Andrews, and H. Bjornsson. 1986. Cold hardiness and ice tolerance of pasture grasses grown and tested in controlled environments. Can. J. Plant Sci. 66:601-608.

Gusta, L.V., J.D. Butler, C. Rajashekar, and M.J. Burk. 1980. Freezing resistance of perennial turfgrasses. HortScience 15:494-496.

Humphreys, M.O. 1989. Assessment of perennial ryegrass (Lolium perenne $\mathrm{L}$.) for breeding: II. Component of winter hardiness. Euphytica 41:99-106.

Maier, F.P., N.S. Lang, and J.D. Fry. 1994. Evaluation of an electrolyte leakage technique to predict St. Augustinegrass freezing tolerance. HortScience 29:316-318.

Meyer, W.A. and C.R. Funk. 1989. Progress and benefits to humanity from breeding cool-season grasses for turf, p. 31-48. In: D.A. Sleper et al. (eds.). Contributions from breeding forage and turf grasses. CSSA. Spec. Publ. 15. CSSA, Madison, Wis.

Murdoch, C.L., A.E. Dudeck, and C.L. Guy. 1990 Development of a technique for screening St Augustinegrass for cold tolerance. Turfgrass Res. Fla. p. 52-63.

NE-57 Technical Research Committee. 1977. Northeast regional turfgrass evaluation of Kentucky bluegrass (Poa pratensis L.), 1968-1973. Pennsylvania Agr. Expt. Sta. Bul. 814.

NRCC Report. 1998. Northeast regional climate center.Cornell Univ.http://met-www.cit.cornell.edu/ nrcc database.htm. 8 May 1998.

Rajashekar, C., D. Tao, and P.H. Li. 1983. Freezing resistance and cold acclimation in turfgrass. HortScience 18:91-93.

Shibata, S. and T. Shimada. 1986. Anatomical observations on the development of freezing injury in cocksfoot crown. J. Jpn. Soc. Grassland Sci. 32:197-204.

Steponkus, P.L. 1978. Cold hardiness and freezing injury of agronomic crops. Adv. Agron. 30:5178

Tanino, K.K. and B.D. McKersie. 1985. Injury within the crown of winter wheat seedlings after freezing and icing stress. Can. J. Bot. 63:432436.

Turgeon, A.J. 1999. Turfgrass management. Prentice-Hall Co., Reston, Va.

Uemura, M. and P.L. Steponkus. 1994. A contrast of the plasma membrane lipid composition of oat and rye leaves in relation to freezing tolerance. Plant Physiol. 104:479-496.

Uemura, M., R.A. Joseph, and P.L. Steponkus. 1995. Cold acclimation of Arabidopsis thaliana L. Plant Physiol. 109:15-30.

U.S. Department of Agriculture. 1997. National Perennial Ryegrass Test-1994. NTEP no. 97-2. USDA, ARS, and National Turfgrass Federation, Beltsville, Md.

Watson, J.R., H.E. Kaerwer, and D.P. Martin. 1992. The turfgrass industry, p. 29-88. In: D.V. Waddington, R.N. Carrow, and R.C. Shearman (eds.). Turfgrass-Agronomy Monograph no. 32. ASA, CSSA, and SSSA, Madison, Wis.

Young, W.C., III, and R.E. Baker. 1995. Perennial ryegrass (Lolium perenne $\mathrm{L}$.) seed production in Oregon, p. 129. Agronomy abstracts. ASA, Madison, Wis.

White, D.B. and M.H. Smithberg. 1980. Cold acclimation and deacclimation in cool-season grasses, p. 149-154. In: J.B. Beard (ed.). Proc. $3^{\text {rd }}$ Intl. Turfgrass Res. Conf., Munich, Germany. 11-13 July 1977. Intl. Turfgrass Soc., ASA, CSSA, and SSSA, Madison, Wis.

Zhu, G.H. and Z.Q. Liu. 1987. Determination of median lethal temperature using the logistical function, p. 291-298. In: P.H. Li (ed.). Plant cold hardiness. Alan R. Liss, New York. 